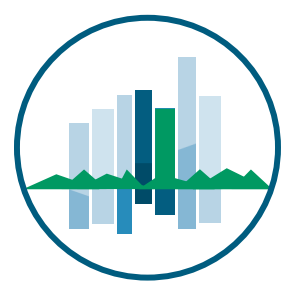

True Smart and Green City?

8th Conference of the

International Forum on Urbanism

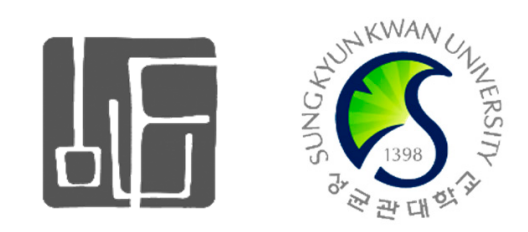

Conference Proceedings Paper

\title{
Water-Energy-Food Nexus of Concave Green-Roof in SNU
}

\author{
Soyoung Baek and Mooyoung Han * \\ $\mathrm{gu}$, Seoul, Korea \\ * Author to whom correspondence should be addressed; Tel.: +82-2-880-8915; \\ E-mail: myhan@snu.ac.kr
}

Department of Civil and Environmental Engineering, Seoul National University, 599 Gwanak-ro, Gwanak-

\begin{abstract}
The impacts of climate change on urban flood, urban heat island and lack of farmland according to rapid urbanization are expected to widespread and severely influencing to socioeconomic conditions. The green roof system within cities is now recognized as a means of alternative solution to urban flood, heat island phenomenon and producing food. In this study, the concave green roof and normal roof are compared on the \#35 building in Seoul National University, Seoul, Korea. The objective of this study is to validate effect of (1) urban flood mitigation, (2) reducing urban heat island and (3) producing food. For the effect of urban flood mitigation, the concave green roof system retains and stores the rainwater in soil and $10 \mathrm{~cm}$ side wall. The concave green roof system of which area is $140 \mathrm{~m}^{2}$ showed effect of flood mitigation reducing peak flow quantity of $56 \%$, peak time delay of 3 hours and storing rainwater of 6.7 ton. For the effect of urban heat island mitigation, the temperature difference of $24^{\circ} \mathrm{C}$ was monitored comparing to the normal roof. For urban agriculture, this green roof $\left(420 \mathrm{~m}^{2}\right)$ is managed over 30 households near campus. In this roof garden, various types of crops (e.g., vegetable, root crops, and fruits) are achievable. Also, this can make contribution to local citizen food security and social community development. Many creative and innovative activities were made possible at the green roof by the community such as musical concert, community lunch, green product donation movement, etc. By applying green roof system on the buildings, without destroying existing urban infrastructure, there will be environmental \& economic benefits and place for urban farming can be secured where people can improve not only their food self-sufficiency but also social community activities.
\end{abstract}

Keywords: Concave green roof, Heat island reduction, Urban farming, Urban flood mitigation. 


\section{Introduction}

Green roof is gaining much interest for its social benefits such as creating aesthetic and green environment as well as its climate change adaptation capability such as flood mitigation, heat island reduction and reducing building energy consumption by cooling energy consumption during summer (Vijayaraghavan et al., 2012: Virginia, S et al., 2010: Castleton et al., 2010). Therefore, many modern cities in the world are promoting green roofs as their climate change adaptation measure (Kumar and Kaushik, 2005). However, green roof can cause other problems such as increased demand for water, labor and cost (Berghage et al., 2007). Most of the green roof is designed and maintained for a single purpose of landscaping and aesthetic improvement. Moreover any quantitative verification of engineering aspects at a full scale is not well reported. In this study, a full-scale $\left(840 \mathrm{~m}^{2}\right)$ concave green roof is introduced at Building No.35 in Seoul National University (SNU), which consists of flower garden and vegetable garden. Concave green roof is a roof which can retain rainwater at the bottom and top of the soil by simply making the surrounding wall $10 \mathrm{~cm}$ higher than the soil level. The effects of flood mitigation, water conservation, as well as heat island reduction are monitored and analyzed systematically.

Figure. 1. System outline of \#35dong Concave green roof in Seoul National University, Seoul, Korea.
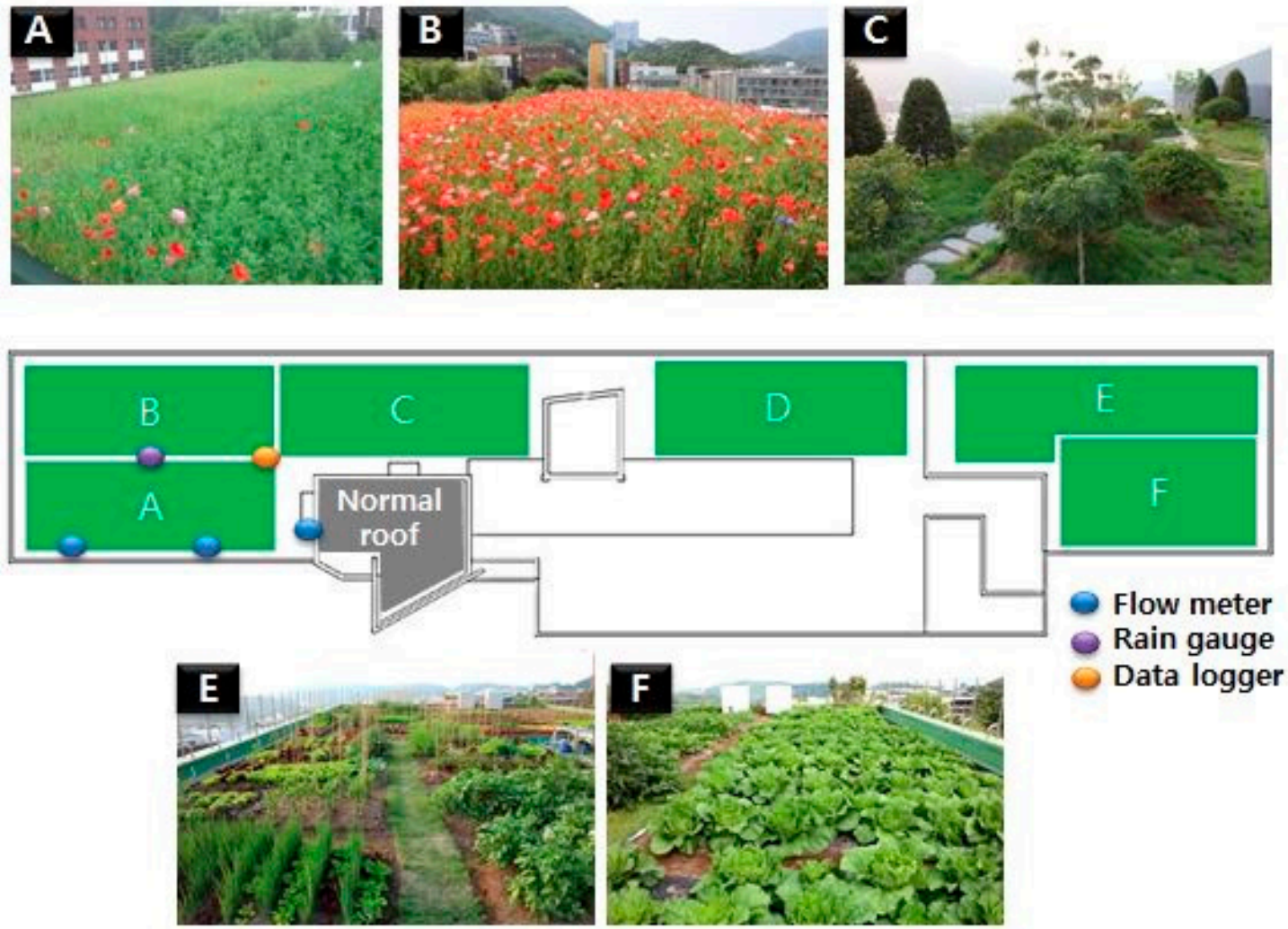

\section{Experimental Section}

This full scale Concave green roof was made at the rooftop of building \#35, Seoul National University (SNU), Seoul, Korea on Dec, 2012 (Figure.1). The flower and vegetable garden of $840 \mathrm{~m}^{2}$ was 
constructed at the $2000 \mathrm{~m}^{2}$ roof. The green roof consists of 6 parts of $140 \mathrm{~m}^{2}$ each. Sensors for measuring runoff, temperature were installed in section $\mathrm{A}, \mathrm{B}, \mathrm{C}$ for verifying effects in flooding control and temperature reduction. At section D, E and F, vegetable gardens are tended by students, faculty and local residents. All these WEF nexus became possible by slightly changing the section of the garden. There are three types of roof: Ordinary concrete roof, ordinary green roof and concave green roof (Figure.2). In ordinary concrete roof, most of the rain is drained quickly in ordinary roof and dries quickly and is heated easily causing heat island effect. Furthermore, solar heat is transferred to the top floor of the building easily and it cause high cooling energy consumption. In the ordinary green roof, water management has not been considered seriously. Most of the rainwater is design to flow down to the drain to avoid any harmful effect to the plants. And later, if needed, water is used for irrigation purpose. However, in the concave green roof, rainwater is retained in drain board at the bottom which can contain rainwater $20 \mathrm{~L} / \mathrm{m}^{2}$ and above the top soil by making the surrounding wall $10 \mathrm{~cm}$ higher than soil level.

Figure 2. Cross section of three types of roofs.

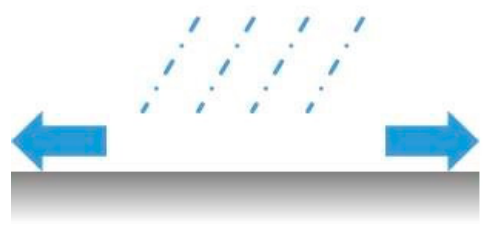

Ordinary roof

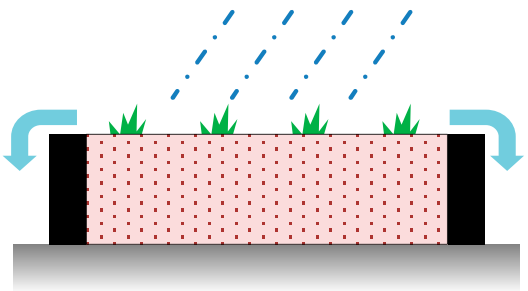

Ordinary green roof

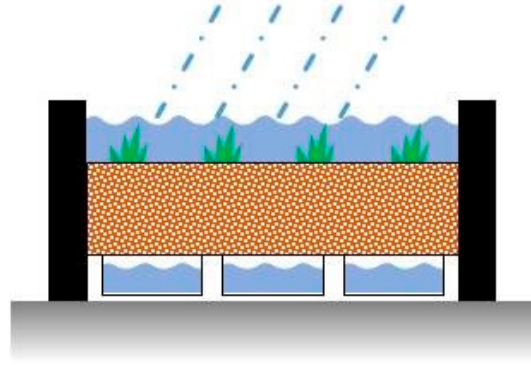

Concave green roof

As in Figure 3, the $100 \mathrm{~m}^{2}$ area of normal roof and the $140 \mathrm{~m}^{2}$ area of concave green roof are compared at Seoul National University \#35 building, Seoul, Korea. The area of normal roof has concrete surface with grade and drains through drainpipe which has a flow meter (Model : Signet 2507 mini Flow Rotor Sensor). The cross section of concave green roof consists of drainage layer $(5 \mathrm{~cm})$, then fabric, artificial soil $(15 \mathrm{~cm})$. The top layer is for planting $20 \mathrm{~cm}$ height of flowers approximately $160 \mathrm{units} / \mathrm{m} 2$. The green roof is able to store $20 \mathrm{~L}$ water per $1 \mathrm{~m}^{2}$ and there is free space for making concave type green roof system by making the side wall $10 \mathrm{~cm}$ higher for temporary storage during heavy rain. The discharge and rainfall were checked by installing flow meters at each drain outlet and a rain gauge. (Model : HD2013 TIPPING BUCKET RAIN GAUGE, DELTA OHM.)

\section{Results and Discussion}

Ordinary roof and ordinary green roof is designed to drain rainwater as fast as they can. On the contrary, the concave green roof system can do a multiple role in water management such as flooding mitigation and water conservation. At an extreme rainfall event on July 12, 2013, where total precipitation amount was recorded as $239 \mathrm{~mm}$ with warning of heavy rain, the concave green roof showed a big potential for flood mitigation (figure. 4) The result showed peak flow quantity reduction of $56 \%$ and peak flow time delay of 3 hours. Furthermore after the rain, the roof retained $6.7 \mathrm{~m}^{3}$ of rainwater $/ 140 \mathrm{~m}^{2}$ section, which can later be used for evapotranspiration for cooling and reducing the irrigation water consumption. 
Figure 3. Cross section of normal roof and concave green roof system.

Normal roof

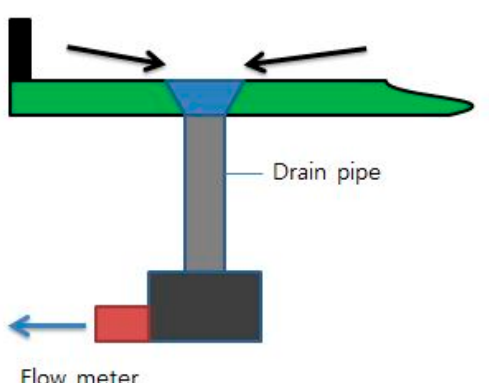

Concave green roof

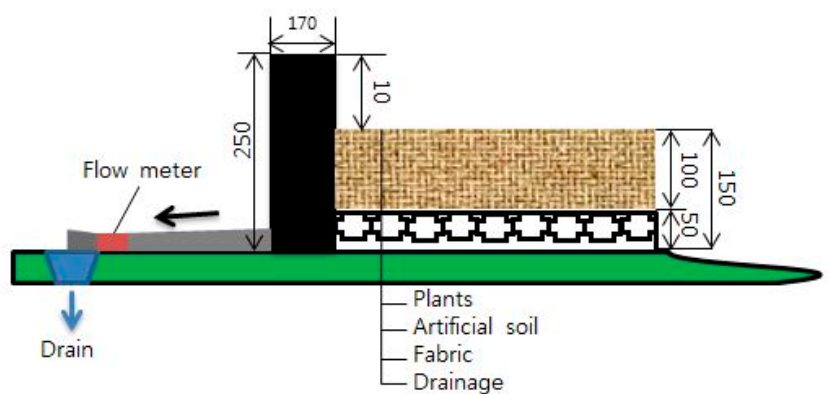

Figure 4. Runoff at Normal roof and Concave green roof on July 12th, 2013.

2013. 7. 12 13 \% Heavy rain warning (Total $239 \mathrm{~mm}$ )

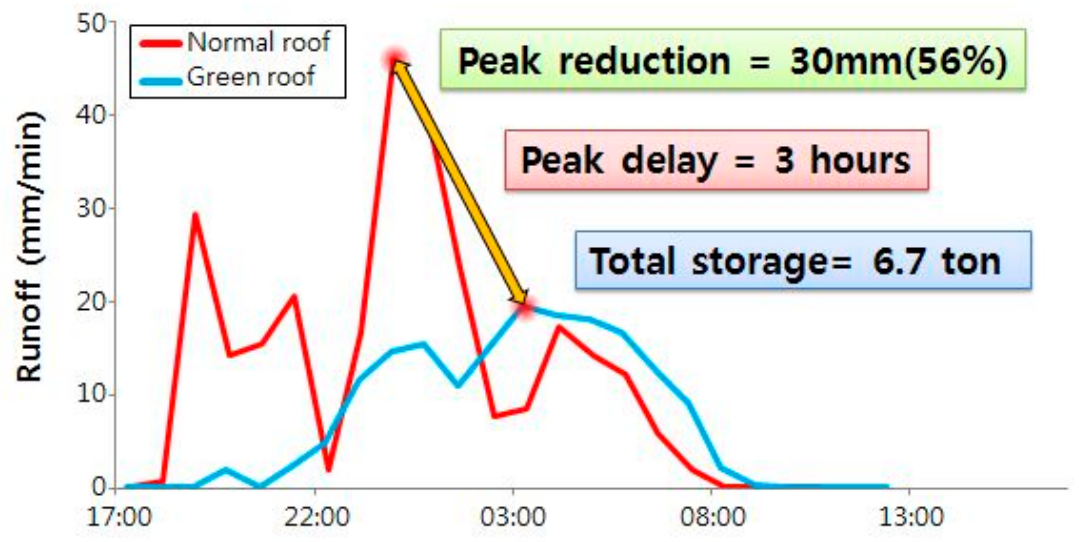

In Energy management, the concave green roof system can reduce the temperature increase by plant cover with extra cooling effect due to evapotranspiration by stored rainwater. In field experiment, on August 30, 2014, it showed maximum surface temperature was $47.9^{\circ} \mathrm{C}$ on the normal roof and $23.9^{\circ}$ on the concave green roof (figure. 5). So, the maximum temperature difference between the normal roof and the concave green roof was $24^{\circ} \mathrm{C}$. Through green roof's cooling effect, it can reduce urban heat island phenomenon and improve building insulation cuts down the cooling energy.

In Food management, through the preservation of the rainwater at concave green roof system, growth of vegetables and fruits would require less maintenance for watering. The vegetable garden is managed by students, faculty members and local residents, which is consist more than 30 households (figure. 6.) Through urban agriculture on green roof, they are self-sufficient in food production such as vegetable, root crops and fruits. There are additional social benefits cannot be quantified. This vegetable garden became a place for communication between school and local residents. Every month, participants of urban faming on \#35-dong green roof gather, share their harvested crops and make and donates from scratch. Besides, Korea Beekeeping Association set 8 hives on green roof and they extract $40 \mathrm{~kg}$ of honey a year. Thus, this green roof exists as a learning place for students and urban farmers. This project already became a showcase in Korea as well as in the world: more than 4,000 people from Korea and other countries visited this green roof in 2014. Green roof as an urban farming and community place, it 
takes the form of a social movement for sustainable communities and reflects varying social development.

Figure 5. Surface temperature at Normal roof and Concave green roof on August 30th 2014.

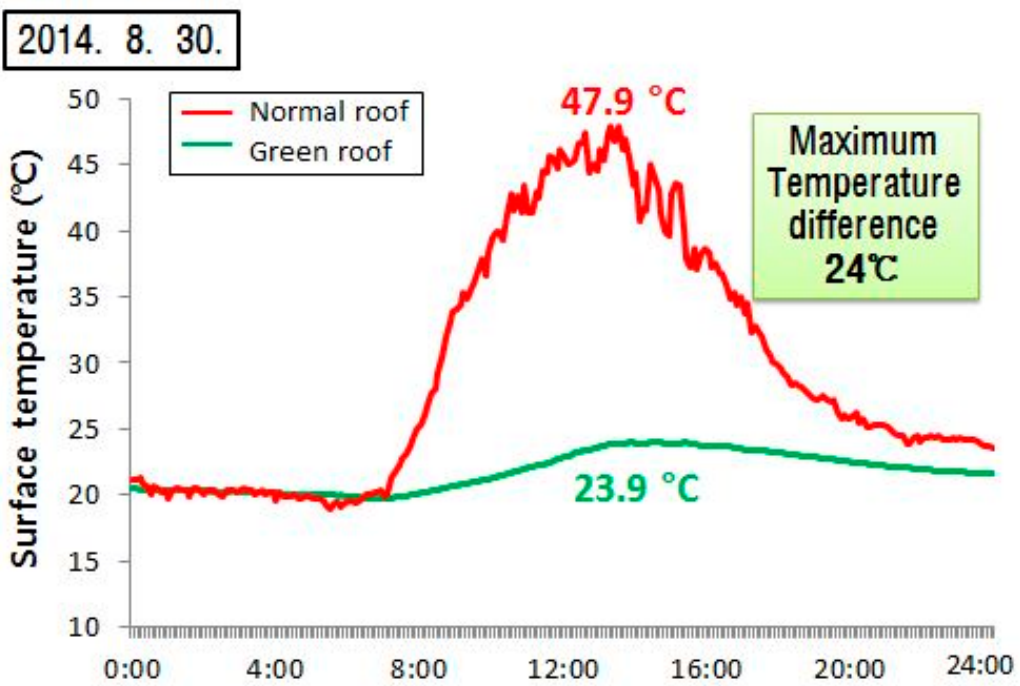

Figure 6. Various events with local residents on green roof.
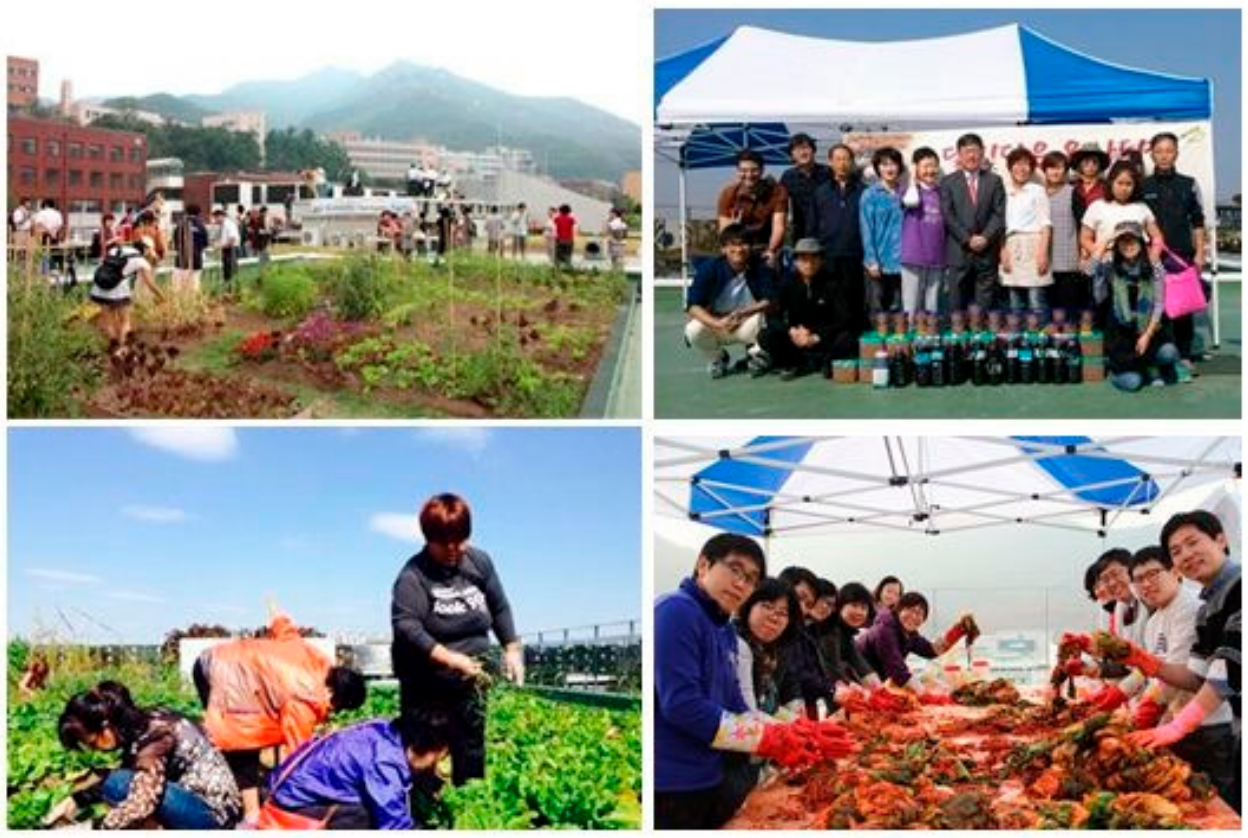

\section{Conclusions}

Concave green roof system was suggested as a sustainable solution to urban flood, urban heat island phenomenon. It also has social benefits of producing food and being community space for people. Not only the building users, but also the local residents can benefit from this concave green roof system. By applying green roof system on the buildings, without destroying existing urban infrastructure, there will be environmental \& economic benefits. This concave green roof which makes everybody happy is already reported in media more than 30 times and awarded at the 2014 Energy Globe Awards, 2015 7th 
World Water Forum Showcase Awards as an urban management model for water-energy-food nexus. After all, this project implies that a simple change from the normal roof to concave green roof system is a sustainable solution for water, energy and food issues of the future, especially as a measure for climate change adaption.

\section{References and Notes}

1. Vijayaraghavan, K., Joshi, U.M., Balasubramanian, R. A field study to evaluate runoff quality from green roofs. Water Res 2012, 46, 1337e1345.

2. Virginia, S., Gianni, V., Hartini, K. The hydrological performance of a green roof test bed under UK climatic conditions, Journal of Hydrology 2010, 414-415, 148-161.

3. H.F. Castleton, V. Stovin, S.B.M. Beck, J.B. Davison. Green roofs; building energy savings and the potential for retrofit, Energy and Buildings 2010, 42, pp. 1582-1591

4. Kumar, R., Kaushik, S. Performance evaluation of green roof and shading for thermal protection of buildings. Building and Environment 2005, 40, 1505-1511.

5. R. Berghage, A. Jarrett, D. Beattie, K. Kelley, S. Hussain, F. Rezai, B. Long, A. Negassi, R. Cameron, W. Hunt. Quantifying Evaporation and Transpirational Water Losses from Green Roofs and Green Roof Media Capacity for Neutralizing Acid Rain, 2007 Retrieved November 2010, from http://www.ndwrcdp.org/research_project_04-DEC-10SG.asp

(C) 2015 by the authors; licensee MDPI and IFoU, This article is an open access article distributed under the terms and conditions of the Creative Commons Attribution license. 